\title{
FUNKCJA WYCHOWAWCZA PIELĘGNIARKI W ASPEKCIE ICNP®
}

\section{THE EDUCATIONAL FUNCTION OF THE NURSE IN THE LIGHT OF THE ICNP®}

\author{
Hanna Grabowska ${ }^{1}$, Halina Nowakowska ${ }^{2}$, Władysław Grabowski ${ }^{1}$, \\ Aleksandra Gaworska-Krzemińska ${ }^{3}$
}

\author{
Pracownia Umiejętności Pielęgniarskich \\ Zakład Zarządzania w Pielęgniarstwie \\ Gdański Uniwersytet Medyczny \\ ${ }^{2}$ Pracownia Metodyki i Dydaktyki \\ Zakład Zarządzania w Pielęgniarstwie \\ Gdański Uniwersytet Medyczny \\ ${ }^{3}$ Zakład Zarządzania w Pielęgniarstwie \\ Gdański Uniwersytet Medyczny
}

DOI: https://doi.org/10.20883/pielpol.2017.75

\section{STRESZCZENIE}

W opinii Międzynarodowej Rady Pielęgniarek pielęgniarki powinny prowadzić edukację zdrowotną, wspierać inicjatywy kampanii informacyjnych. Problematyka oddziaływania wychowawczego pielęgniarek w rodzimym pielęgniarstwie nie jest zupełnie nowa. Pojęciem funkcji wychowawczej/psychopedagogicznej posługiwały się pionierki polskiego pielęgniarstwa. Również aktualne standardy kształcenia dla kierunku studiów pielęgniarstwo zawierają efekty kształcenia odnoszące się do zadań wynikających z omawianej funkcji.

Celem niniejszego opracowania jest ukazanie funkcji wychowawczej realizowanej przez pielęgniarki w aspekcie ICNP®).

Funkcja wychowawcza dotyczy zamierzonego wpływu na osobowość pacjenta, kształtowania u niego pożądanych zachowań zdrowotnych, poczucia odpowiedzialności za własne zdrowie, przygotowania podopiecznego do współpracy w procesie pielęgnowania i do samoopieki.

Międzynarodowy, ujednolicony język terminologii stosowany w systemie opieki pielęgniarskiej zawiera stosunkowo wiele pojęć opisujących działania i interwencje w zakresie omawianej funkcji. Wywodzą się one z pojęcia nadrzędnego „informowanie” i skupione są wokół takich pojęć, jak: nauczanie, ukierunkowywanie, wyjaśnianie. Terminami o węższym znaczeniu są m.in.: edukowanie, instruowanie, doradzanie, poradnictwo czy udzielanie wskazówek na przyszłość. Inną kategorię stanowią terminy opisujące udział pielęgniarek w udzielaniu wsparcia, wzmacnianiu osiągnięć pacjenta. Zaliczyć do nich można chociażby: promowanie, motywowanie, wspieranie, wzmacnianie, a także zachęcanie. Na kanwie przytoczonych terminów, wywodzących się z osi „działanie”, sformułowano bardzo liczne, gotowe do zastosowania interwencje pielęgniarskie.

Międzynarodowa klasyfikacja praktyki pielęgniarskiej (ICNP®) umożliwia w pethi opisywanie i dokumentowanie wszystkich zadań wynikających z realizowanej przez pielęgniarki funkcji wychowawczej.

SŁOWA KLUCZOWE: klasyfikacja, edukacja zdrowotna, pielęgniarka.

\begin{abstract}
According to the International Council of Nurses, nurses should be involved in health education and support initiatives for information campaigns. The issue of the educational impact of nurses in family nursing is not entirely new. The notion of the educational, pedagogical and psychological function was utilized by the pioneers of Polish nursing. Also, the current educational standards for the Nursing field of study contain learning outcomes associated with the tasks arising from this function.

The aim of this paper is to show the educational function as performed by nurses in association with ICNPß).

The educational function concerns the intended impact on the personality of the patient, shaping the desired health-related behavior, evoking a sense of responsibility for their own health, preparing the patients to cooperate in the process of nursing and self-care.

The international, standardized terminology used in the nursing care system contains a relatively large number of concepts describing actions and interventions relating to this function. They derive from the master concept of 'nformation' and are centered around such concepts as: teaching, directing, explaining. There are also terms of a narrower meaning, such as education, instruction, advising, counseling, or providing guidance for the future. There is a separate category of terms describing the participation of nurses in providing support, reinforcing patient's achievements. The category includes promoting, motivating, supporting, reinforcing, and encouraging. On the basis of the listed terms derived from the action axis a lot of ready-to-use nursing interventions can be formulated.

The International Classification for Nursing Practice (ICNP®) enables a complete description and documentation of all the tasks relating to the educational function of the nurses.
\end{abstract}

KEYWORDS: classification, health education, nurse. 


\section{Wprowadzenie}

W opinii Międzynarodowej Rady Pielęgniarek w prewencji chorób przewlekłych, oprócz indywidualnego oddziaływania w miejscu świadczonych usług, pielęgniarka powinna wspierać inicjatywy kampanii informacyjnych i edukacji zdrowotnej, udzielać jasnych i spójnych wskazówek sprzyjających utrzymaniu zdrowia [1].

Problematyka oddziaływania wychowawczego pielęgniarek w rodzimym pielęgniarstwie nie jest zupełnie nowa. Pojęciem funkcji wychowawczej/psychopedagogicznej posługiwały się pionierki polskiego pielęgniarstwa [2, 3]. Chrzanowska, twórczyni pielęgniarstwa w otwartej opiece zdrowotnej, wśród powinności zawodowych pielęgniarki wyodrębniła: rolę psychologa, rolę nauczyciela i rolę pracownika socjalnego $[4,6]$. Z kolei Kulczyńska wyróżniła funkcje: opiekuńczą, wychowawczą i zarządzania. W opinii Kulczyńskiej zakres pracy pielęgniarki powinien obejmować przygotowanie człowieka do utrzymania własnego zdrowia, stąd niezbędna pielęgniarce jest wiedza pedagogiczna $[5,6]$. Hutner twierdziła, że celem pielęgnowania jest racjonalne inwestowanie w zdrowie człowieka, a zdrowie jest wartością pozytywną, którą należy chronić i pomnażać [5]. Według Minczewskiej pielęgniarka pełni funkcję doradcy i wychowawcy, pomagając pacjentowi/grupie świadomie kształtować warunki życia i pracy oraz postępować w sposób ułatwiający przystosowanie [6]. Natomiast zdaniem Mazurkiewicz pielęgniarki pełnią zadania ogólnopedagogiczne, pedagogiczno-zdrowotne i pedagogiczno-zawodowe w ramach „pielęgnacji wychowującej”, integrującej pielęgnowanie z wychowaniem zdrowotnym, oraz „działalności wychowawczej”, obejmującej kształtowanie potocznych zachowań zdrowotnych, ściśle związanych z realizacją pielęgnacji [7].

W latach 80. XX wieku Wołynka w klasyfikacji funkcji zawodowych realizowanych przez pielęgniarki zawarła funkcję wychowawczą, wiążącą się z profilaktyką chorób, przekazywaniem wiedzy o zdrowiu, wpajaniem zasad higieny osobistej, żywienia, pracy i wypoczynku [8]. Z kolei kilka lat później Lenartowicz, opisując funkcję wychowawczą, stwierdziła, że wiąże się ona z kształtowaniem aktywnej postawy każdego człowieka wobec własnego zdrowia i zdrowia otoczenia, a Poznańska wprowadziła pojęcie funkcji psychopedagogicznej, polegającej na kształtowaniu pożądanych zachowań zdrowotnych pacjenta [7].

Współcześnie w Polsce przyjmuje się najczęściej dwa podejścia do klasyfikacji funkcji zawodowych realizowanych przez pielęgniarki, jedno - prezentowane przez Światową Organizację Zdrowia (WHO) - oraz drugie - odnoszące się do klasyfikacji zaproponowanej przez Ciechaniewicz. W klasyfikacji WHO wyodrębniono cztery kluczowe funkcje realizowane przez pielęgniarki w ich codziennej praktyce zawodowej. Te funkcje to: świadczenie i zarządzanie opieką zdrowotną, uczenie odbiorców usług pielęgniarskich oraz personelu opieki zdrowotnej, działanie w roli członka zespołu opieki zdrowotnej, a także działanie na rzecz rozwoju praktyki pielęgniarskiej w drodze krytycznego myślenia i badań [9]. Ciechaniewicz w roku 1996 zdefiniowała funkcję wychowawczą jako tę, która „dotyczy zamierzonego wpływu na osobowość pacjenta, kształtowania u niego pożądanych zachowań zdrowotnych, poczucia odpowiedzialności za własne zdrowie, przygotowania podopiecznego do współpracy w procesie pielęgnowania i do samoopieki". Do zadań realizowanych w ramach funkcji wychowawczej zaliczyła: kształtowanie poczucia odpowiedzialności za własne zdrowie (kształtowanie przekonań, systemu wartości, wpływanie na emocje i uczucia), przygotowanie chorych do podejmowania działań prozdrowotnych, przygotowanie pacjenta do współpracy z pielęgniarkami w procesie pielęgnowania oraz stosowania zalecanych metod terapii [10].

Bez względu jednak na sposób kategoryzacji funkcji i zadań zawodowych pielęgniarka powinna posiadać m.in. umiejętność udzielania świadczeń z zakresu promowania zdrowia i prewencji chorób (w tym rozpoznawania czynników ryzyka wynikających ze stylu życia), prowadzenia edukacji zdrowotnej jednostki i grupy społecznej (m.in. motywowania odbiorców do podejmowania zachowań prozdrowotnych, uczenia sposobów samokontroli stanu zdrowia, kształtowania prawidłowych zachowań zdrowotnych), komunikacji interpersonalnej oraz inicjowania i wspierania działań społeczności lokalnej na rzecz zdrowia, udzielania wsparcia społecznego $[1,10,11]$.

Również aktualne standardy kształcenia dla kierunku studiów pielęgniarstwo zawierają efekty kształcenia odnoszące się do zadań wynikających z omawianej funkcji. Obejmują one proces uczenia odbiorcy usług pielęgniarskich samokontroli stanu zdrowia i motywowania do zachowań prozdrowotnych, realizację programów promocji zdrowia i edukacji zdrowotnej dostosowanych do rozpoznanych potrzeb zdrowotnych [12].

Celem niniejszego opracowania jest ukazanie funkcji wychowawczej realizowanej przez pielęgniarki w aspekcie ICNP®.

\section{Omówienie}

Międzynarodowy, ujednolicony język terminologii stosowany w systemie opieki pielęgniarskiej (Międzynarodowa klasyfikacja praktyki pielęgniarskiej - ICNP®) zawiera stosunkowo wiele pojęć opisujących działania i interwencje w zakresie omawianej funkcji [13]. Wywodzą się one z pojęcia nadrzędnego „informowanie” zde- 
finiowanego jako „mówienie komuś o czymś” i skupione są wokół takich pojęć, jak: nauczanie, opisywanie, ukierunkowywanie, wyjaśnianie (Rycina 1).

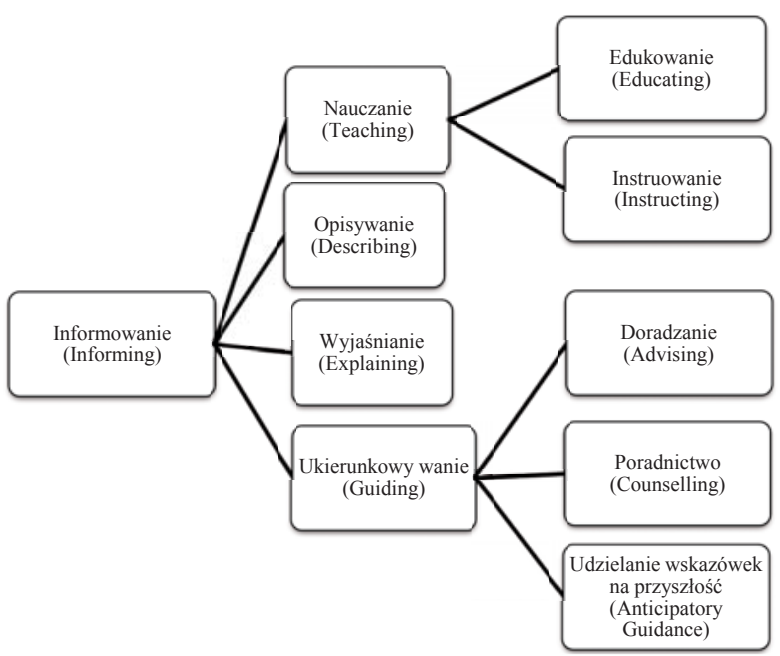

Rycina 1. Zakres pojęciowy terminu „informowanie” Figure 1. Scope of the conceptual term 'information'

Źródło: badania własne

Source: author's own materials

Nauczanie polega na przekazywaniu komuś wiedzy na temat zagadnień zdrowotnych w uporządkowany, systematyczny sposób, natomiast opisywanie - na określaniu cech, wyglądu itd. kogoś lub czegoś w formie ustnej bądź pisemnej. Ukierunkowywanie to taki rodzaj informowania, który charakteryzuje się kierowaniem kimś w podejmowaniu decyzji dotyczących kwestii zdrowotnych, a z kolei istotą wyjaśniania jest „uczynienie czegoś przejrzystym lub prostym dla kogoś” [13]. Z terminu „nauczanie” wywodzą się pojęcia: edukowania (tj. przekazywania wiedzy komuś o czymś) oraz instruowania (oznaczającego udzielanie systematycznych informacji komuś o tym, jak coś zrobić). Odmianę instruowania stanowi szkolenie - termin określający rozwijanie umiejętności kogoś lub funkcji czegoś. Ukierunkowywanie stanowi zaś termin nadrzędny w stosunku do doradzania (czyli sugerowania odbiorcy, że promowany sposób działania należy podjąć) i dotyczy udzielania wskazówek na przyszłość (czyli nadawania osobom kierunku postępowania w kwestiach zdrowotnych przed wystąpieniem zdarzenia) oraz poradnictwa oznaczającego ułatwianie komuś poprzez dialog podjęcie samodzielnej decyzji [13].

Na kanwie przytoczonych terminów, wywodzących się z osi „działanie”, sformułowano bardzo liczne, gotowe do zastosowania interwencje pielęgniarskie, których przykłady zawarto poniżej.

Aktualna wersja ICNP® zawiera prawie 170 interwencji związanych z nauczaniem pacjenta, opiekunów oraz członków rodziny, które w autorskim podziale oraz wybranym zakresie zaprezentowano poniżej.
1. Interwencje ogólne (nauczanie pacjenta, informowanie o hospitalizacji, nauczanie o chorobie/ procedurze/reżimie terapii/leku/prewencji nawrotów/urządzeniu).

2. Styl życia (nauczanie o nadużywaniu alkoholu/narażeniu na bierne palenie/rzucaniu palenia/zachowaniach prozdrowotnych/zarządzaniu stresem).

3. Układ oddechowy $i$ sercowo-naczyniowy (nauczanie o terapii inhalacyjnej/tlenowej/rozruszniku serca/terapii przeciwzakrzepowej, nauczanie technik oddechowych).

4. Układ regulacyjny (nauczanie o obrzęku/odwodnieniu/pielęgnacji owrzodzenia cukrzycowego/przyjmowaniu płynów).

5. Układ pokarmowy (nauczanie o karmieniu dojelitowym/pielęgnacji sondy nosowo-żołądkowej/ technice odklinowania/treningu jelit/zarządzaniu biegunką/nudnościami/irygacji kolostomii/ nauczanie o komplikacjach stomii).

6. Układ moczowy (nauczanie o dializie otrzewnowej/hemodializie/irygacji pęcherza moczowego/ pielęgnacji cewnika urologicznego/zarządzaniu nietrzymaniem moczu, nauczanie samodzielnego cewnikowania).

7. Układ nerwowy i narządy zmysłu (nauczanie o terapii odwracającej uwagę/efektywnym komunikowaniu, nauczanie technik pamięciowych, nauczanie o pielęgnacji oka/pielęgnacji ucha, nauczanie technik adaptacyjnych w deficycie sensorycznym).

8. Mobilność/rehabilitacja (nauczanie o ćwiczeniach/ fizjoterapii klatki piersiowej/pielęgnacji protezy/ unieruchomieniu/prewencji upadków/technice chodzenia/technikach przemieszczania).

9. Położnictwo/pediatria (nauczanie masażu niemowlęcia, nauczanie o antykoncepcji/ciąży/ efektywnym rodzicielstwie/niepłodności/pielęgnacji krocza/pielęgnacji poporodowej/planowaniu rodziny/porodzie/zachowaniach seksualnych/bezpieczeństwie dziecka/karmieniu niemowlęcia/karmieniu piersią/pielęgnacji niemowlęcia/więzi opiekuna z dzieckiem).

10. Dyscypliny zabiegowe (nauczanie o gojeniu się rany/pielęgnacji drenu do drenażu/pielęgnacji rany/pielęgnacji tracheostomii/pielęgnacji złamania/zmianie opatrunku na ranie).

11. Onkologia/opieka paliatywna (nauczanie o chemioterapii/hospicjum/procesie umierania/radioterapii).

12. Samokontrola, samoopieka, opieka nieprofesjonalna (nauczanie o pomiarze ciśnienia krwi/ samoopiece/pielęgnacji stopy/potrzebach dietetycznych/zarządzaniu bólem/kontrolowaniu 
objawów podmiotowych/usłudze samopomocy/ bezpieczeństwie w domu, nauczanie opiekuna, nauczanie rodziny o chorobie/prewencji upadków/reżimie diety/technikach przemieszczania/ terapii płynami/teście diagnostycznym/urządzeniu/usługach społecznych/wzorcu higieny/zarządzaniu bólem).

Jedyną interwencję należącą do kategorii „wyjaśnianie” stanowi „wyjaśnianie praw pacjenta”. W zakresie ukierunkowywania - doradzania zawarte zostały 2 interwencje: doradzanie o możliwościach mieszkaniowych oraz doradzanie o zatrudnieniu, natomiast ukierunkowywanie - poradnictwo zostało opisane przez pryzmat 9 interwencji, takich jak: poradnictwo dla pacjenta, poradnictwo dotyczące alkoholu, poradnictwo dotyczące karmienia piersią, poradnictwo dotyczące nadużywania specyfików, poradnictwo dotyczące nadziei, poradnictwo dotyczące stosowania tytoniu, poradnictwo dotyczące strachu, poradnictwo dotyczące stresu duchowego i poradnictwo genetyczne [13].

W wyniku dokonanej pod kątem funkcji wychowawczej analizy zawartości ICNP® wyodrębniono jeszcze jedną kategorię skupiającą terminy wywodzące się z ogólnego pojęcia asystowania, odnoszące się jednakże do udziału pielęgniarek w podtrzymywaniu i udzielaniu wsparcia odbiorcom świadczeń w zakresie ich zasobów samoopiekuńczych oraz dotyczących współpracy z zespołem interdyscyplinarnym. Zaliczyć do nich można promowanie, ułatwianie i wspieranie (Rycina 2).

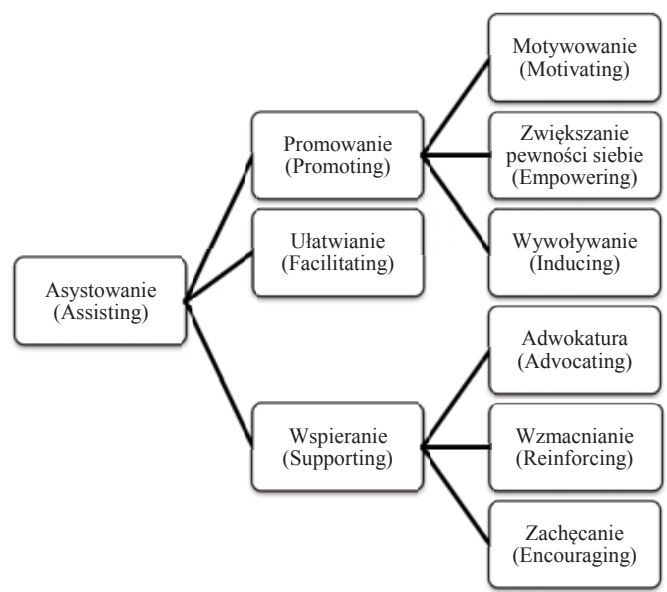

Rycina 2. Zakres pojęciowy terminu „asystowanie" Figure 2. Scope of the conceptual term 'assisting'

Źródło: badania własne

Source: author's own materials

W ICNP® asystowanie zdefiniowano jako „wykonywanie części pracy z kimś lub dla kogoś”. Jest to termin nadrzędny w stosunku do promowania (oznaczającego pomaganie komuś w rozpoczęciu lub dalszej realizacji czegoś), ułatwiania (polegającego na uczynieniu czegoś łatwiejszym dla kogoś) oraz wspierania (oznaczającego udzielanie pomocy socjalnej lub psychologicznej potrzebnej komuś do osiągnięcia celu, ochronę kogoś lub czegoś przed porażką, dźwiganie ciężaru czegoś, utrzymywanie pozycji, podtrzymywanie). Promowanie obejmuje swoim zakresem takie terminy, jak: motywowanie (tj. ukierunkowanie czyjegoś działania lub zainteresowania działaniem), wywoływanie (czyli pomoc w rozpoczęciu czegoś), a także zwiększanie pewności siebie (umożliwienie osobom dokonania wyboru w celu wykorzystania ich potencjału na rzecz poprawy zdrowia) [13].

Klasyfikacja zawiera 48 interwencji odnoszących się do pojęcia „,promowanie”, których przykłady podano poniżej.

1. Interwencje ogólne (promowanie akceptacji statusu zdrowotnego/przestrzegania reżimu/ samodzielnego zarządzania objawami).

2. Status fizjologiczny (promowanie ćwiczeń/ efektywnego wydalania moczu/mobilności fizycznej/pozytywnej termoregulacji/rutyny wypróżnień/używania okularów).

3. Status psychologiczno-duchowy (promowanie efektywnego radzenia sobie/nadziei/poczucia własnej wartości/wsparcia duchowego).

4. Status społeczny (promowanie efektywnego komunikowania się w rodzinie/pozytywnych relacji/roli opiekuna/wsparcia rodziny/wsparcia społecznego).

5. Samoopieka/styl życia (promowanie higieny/ samoopieki/ zachowań prozdrowotnych).

6. Położnictwo/pediatria (promowanie edukacji dotyczącej karmienia piersią w społeczności/ karmienia wyłącznie piersią/rozwoju dziecka/ techniki „skóra do skóry”).

Kolejną grupę interwencji stanowią te, które dotyczą terminu „ułatwianie”. Należy do niej 14 interwencji: ułatwianie akceptacji starzenia, ułatwianie dostępu do leczenia, ułatwianie komunikowania potrzeb, ułatwianie komunikowania uczuć, ułatwianie korzystania ze zdolności do rozmowy o procesie umierania, ułatwianie możliwości wykonywania roli, ułatwianie przejścia przez żal po stracie, ułatwianie przestrzegania reżimu, ułatwianie regeneracji finansowej, ułatwianie rodzinie możliwości do uczestniczenia w planowaniu opieki, ułatwianie wykorzystania zdolności do uczestniczenia w planowaniu opieki, ułatwienie kontrolowania impulsów, ułatwienie regeneracji po nadużywaniu alkoholu, ułatwienie regeneracji po nadużywaniu specyfiku [13].

Równie interesująca wydaje się lista 17 interwencji opisujących aktywność zawodową pielęgniarek 
w zakresie wspierania, do których należą: wspieranie karmienia piersią, wspieranie obrzędów duchowych, wspieranie opiekuna, wspieranie pozytywnego wizerunku ciała, wspieranie procesu radzenia sobie rodziny, wspieranie rodziny, wspieranie rodziny w procesie podejmowania decyzji, wspieranie rodziny w procesie żałoby, wspieranie statusu psychologicznego, wspieranie stosowania terapii tradycyjnej, wspieranie trzymania moczu, wspieranie trzymania stolca, wspieranie w procesie podejmowania decyzji, wspieranie w procesie żałoby, wspieranie wierzeń, wspieranie w procesie godnego umierania, wspieranie zdolności zarządzania reżimem [13].

W perspektywie uszczegółowionej interwencje „wspierania" dotyczą tzw.:

- adwokatury, oznaczającej „zalecanie czegoś lub kogoś poprzez argumentacje”" (2 interwencje ICNP®: adwokatura dla karmiącej piersią, bycie adwokatem pacjenta),

- $\quad$ zachęcania, polegającego na obudzeniu w kimś nadziei lub pewności siebie (3 interwencje: zachęcanie do odpoczynku, zachęcanie do pozytywnych afirmacji, zachęcanie do stosowania techniki oddychania lub odkasływania),

- wzmacniania, oznaczającego „czynienie kogoś lub czegoś silniejszym" (11 interwencji: wzmacnianie kontroli impulsów, wzmacnianie osiągnięć, wzmacnianie pozytywnych zachowań, wzmacnianie przestrzegania zaleceń, wzmacnianie reżimu behawioralnego, wzmacnianie reżimu fizjoterapii, wzmacnianie samoskuteczności, wzmacnianie techniki wykonywania ćwiczeń mięśni lub stawów, wzmacnianie tożsamości osobowej, wzmacnianie umiejętności, wzmacnianie ustalania priorytetów) [13].

Realizując funkcję wychowawczą, pielęgniarki bardzo często demonstrują swoim podopiecznym zalecane sposoby postępowania, w tym stosowania określonych metod terapii. Demonstrowanie wg ICNP® oznacza „przedstawianie w ramach widocznego zachowania”. W jego zakresie sformułowano 4 interwencje: demonstrowanie metod prewencji upadków, demonstrowanie sposobu podawania leku, demonstrowanie technik relaksacyjnych, demonstrowanie techniki wykonywania iniekcji podskórnych [13].

Istotną kwestię - z perspektywy omawianej w niniejszym opracowaniu funkcji - stanowi ocena kompetencji chorego i jego bliskich (ich wiedzy, umiejętności i postaw) w zakresie wdrażania zalecanych sposobów postępowania oraz ewaluacja uzyskanych w toku edukacji zdrowotnej, poradnictwa, udzielonego wsparcia efektów/wyników pielęgnowania. I w tym przypadku ICNP® zawiera bardzo liczne propozycje terminów umożliwiających bardzo rzetelne i szczegółowe opisanie podejmowanych przez pielęgniarki interwencji dotyczących oceny i ewaluacji [13], których przykłady zestawiono poniżej.

1. Ocenianie wiedzy (ocenianie wiedzy o bólu/ chorobie/pielęgnacji rany/prewencji upadków/ reżimie leczenia, ocenianie wiedzy opiekuna).

2. Ocenianie postawy (ocenianie akceptacji statusu zdrowia, ocenianie gotowości do rzucenia palenia/do uczenia/do wypisu, ocenianie postawy wobec choroby/operacji/reżimu terapii/zarządzania leczeniem, ocenianie przekonań kulturowych).

3. Ocenianie potrzeb, możliwości i oczekiwań (ocenianie barier przestrzegania zaleceń/kontroli objawów/możliwości/oczekiwań/potrzeb dotyczących opieki zdrowotnej i opieki społecznej/preferencji/ samoskuteczności/stopnia samodzielności).

4. Ewaluacja (ocenianie reakcji na nauczanie, ewaluacja odpowiedzi psychospołecznej na instruowanie, ewaluacja odpowiedzi psychospołecznej na instruowanie dotyczące bólu/ leku/odżywiania/ćwiczeń/rany).

\section{Podsumowanie}

Zadania zawodowe wynikające z funkcji wychowawczej realizowanej przez pielęgniarki obejmują m.in.: dokonywanie indywidualnej oceny kompetencji odbiorcy w zakresie zachowania i/lub przywracania zdrowia, przygotowywanie i dostarczanie podopiecznym niezbędnych informacji, organizowanie i realizację procesu edukacji zdrowotnej oraz ocenianie skuteczności wdrożonych programów/interwencji edukacyjnych.

Międzynarodowa klasyfikacja praktyki pielęgniarskiej (ICNP®) umożliwia w pełni opisywanie i dokumentowanie wszystkich zadań wynikających z realizowanej przez pielęgniarki funkcji wychowawczej.

\section{Piśmiennictwo}

1. Delivering Quality, Serving Communities: Nurses Leading Chronic Care. Geneva: International Council of Nurses; 2010.

2. Janeczko R. Psychopedagogiczne problemy w pielęgnowaniu chorych. W: Hutner R (red.). Pielęgniarstwo specjalistyczne. Warszawa: PZWL; 1971. 1-28.

3. Łyżwańska N, Chrzanowska H. Pielęgniarstwo w otwartej opiece zdrowotnej. W: Chodorowska-Procner A, Hutner R (red.). Podręcznik dla pielęgniarek. T. 1. Warszawa: PZWL; 1958. 561-635.

4. Chrzanowska H. Pielęgniarstwo w otwartej opiece zdrowotnej. Warszawa: PZWL; 1964. 7-64.

5. Zahradniczek K, Marć M, Górajek-Jóźwik J. Wkład polskich pielęgniarek w rozwój teorii - wybór treści. W: Górajek -Jóźwik J (red.). Filozofia i teorie pielęgniarstwa. Warszawa: PZWL; 2007. 241-269.

6. Franek GA, Łukasz-Paluch K, Cholewka B. Koncepcja roli zawodowej pielęgniarki w literaturze przedmiotu. Probl Piel. 2012; 20(2): 252-259. 
7. Kosińska M. Funkcje pielęgniarki. W: Kosińska M (red.). Wybrane zagadnienia pracy nauczyciela zawodu. Skrypt dla studentów wydziałów pielęgniarskich. Katowice: ŚAM; 2000. 22-29.

8. Wołynka S. Pielęgniarstwo ogólne. Warszawa: PZWL; 1981. 48-59.

9. Salvage J. Pielęgniarstwo w działaniu. Umacnianie pielęgniarstwa i położnictwa na rzecz „zdrowia dla wszystkich”. Warszawa: Zakład Promocji Zdrowia, Instytut Kardiologii; 1997.

10. Ciechaniewicz W. Pieleggniarka. W: Ciechaniewicz W (red.). Pielęgniarstwo. Ćwiczenia. Warszawa: PZWL; 2006. 157-169.

11. Ustawa $z$ dnia 15 lipca 2011 r. o zawodach pielęgniarki i położnej. Dz.U. 2011 Nr 174, poz. 1039 z późn. zm.

12. Rozporządzenie Ministra Nauki i Szkolnictwa Wyższego z dnia 9 maja 2012 r. w sprawie standardów kształcenia dla kierunków studiów: lekarskiego, lekarsko-dentystycznego, farmacji, pielęgniarstwa i położnictwa. Dz.U. 2012 poz. 631.

13. International Council of Nurses. Pillars \& Programmes. Professional Practice. eHealth. International Classification for Nursing Practice (ICNP®). ICNP Browser NEW, http://www.icn.ch/ICNP-Browser-NEW.html (data dostępu: 19.12.2016)
Artykuł przyjęty do redakcji: 15.09.2016

Artykuł przyjęty do publikacji: 10.04.2017

Źródło finansowania: Praca nie jest finansowana z żadnego źródła. Konflikt interesów: Autorzy deklarują brak konfliktu interesów.

\section{Adres do korespondencji:}

Hanna Grabowska

ul. Dębinki 7

80-952 Gdańsk

tel.: 583491980

e-mail: hanna.grabowska@gumed.edu.pl

Pracownia Umiejętności Pielęgniarskich

Zakład Zarządzania w Pielęgniarstwie

Gdański Uniwersytet Medyczny 